\title{
Using RAPD PCR Method for Studying DNA Polymorphism of Agricultural Importance Arthropods
}

\author{
Kil VI* \\ Department of Biology, Kuban State University, Russia \\ Submission: July 26, 2017; Published: August 11, 2017 \\ "Corresponding author : Kil VI, Department of biology, Kuban State University, Krasnodar, Russia, Email: bmafolabi@gmail.com
}

\section{Opinion}

The polymerase chain reaction (PCR) is a method widely used in scientific investigations of different groups of organisms, including benefits and harmful arthropods. At present, the method of random amplified polymorphic DNA (RAPD PCR) is very widespread because it is the most accessible and simple [1]. However, it has a number of limitations for practical application, among which there is the relatively low reproducibility of results, because PCR is dependent on primer, quality and quantity of DNA, magnesium ion concentration, activity of polymerase and a type of the thermal cycler (DNA amplifier).

At the same time we studied effect of a primer on reproducibility of the RAPD PCR analysis in insect populations. As a result we proposed a new approach to obtaining of reproducible results of the RAPD PCR, which is based on identification and use of high specific primers. Such method allows conducting reproducible RAPD analysis of populations without preliminary evaluation of DNA concentrations and standardization of PCR conditions to this parameter [2].

In our laboratory over the years we successfully apply this approach for RAPD analysis of a number of important agricultural insects [3,4]. Key to success of RAPD method using - a highspecific RAPD primer (in relation to DNA of the tested species). This is the main factor effecting reproducibility of results of the RAPD PCR (in maintenance of two other requirements-one PCR machine and one set of reagents).

At the molecular level, the specificity of a RAPD primer is defined by its homology to DNA matrix. Thus, high specificity of a RAPD primer is caused by its high level of binding with studied DNA, which has to be revealed by absence of empty tracks in gel electrophoresis (in correct design of experiment) and presence of a relatively large amount of brightly colored DNA fragments.
Some RAPD primers cannot detect homologies or have low homology with the analyzing DNA (according to our identification, these are low specific primers) and, as a result, the absence of PCR product or its small quantity and low reproducibility. Moreover, some RAPD primers are not able to detect DNA polymorphism in populations that in a majority of cases make them useless for further molecular-genetic analysis of populations (not informative primers).

In this connect researchers should pay particular attention to the preliminary testing of RAPD primers. Choice of primers or use of only reproducible DNA fragments is the basis of effective and successful RAPD analysis of populations, closely related species, and even evaluation of interspecific genetic polymorphism [5-7].

Preliminary screening of primers on specificity to the studied DNA usually does not demand a lot of time. As a rule, it is required to test 15-30 RAPD primers with DNA of the studied species. For estimation of RAPD primers on specificity, the PCR was performed on small sampling of specimens $(n=8-12)$, and high specific primers were selected and checked on their reproducibility and informational content. A high specificity of the primer was revealed on the presence of a relatively large amount of brightly colored DNA fragments and absence of empty tracks in gel electrophoresis, reproducibility of the primer was revealed by the test on sensitivity to different DNA concentrations of one or two studied specimens.

Under high informative content of the primer, we understand a high level of DNA polymorphism of a population identified with its help, and, at the same time, a relatively high average number of DNA fragments per individual. So the testing revealed later highly specific RAPD primers can be used further for assessment of intra specific distinctions of insects, ignoring a difference in concentration of the compared DNA samples. 
At the same time we with success use this method also for the analysis of interspecies distinctions. In this case it is necessary to pick up RAPD primers at the same time high-specific to different types of insects. So, for example, we selected the primers suitable for the phylogenetic analysis of Coccinellidae family (OPA02 and OPA07) [7].

Thus, the approach offered by us based on use of highspecific primers allows to receive high-reproducible results of the molecular-genetic analysis. The RAPD PCR method can be used with success for the analysis intra-and interspecies distinctions of insects and also in assessment of a DNA polymorphism and genetic variety of populations. At the same time, it is important to note that this approach allows to reduce time and money resources for carrying out the reproduced RAPD analysis of populations. He does not demand knowledge of DNA sequence that makes it more available, and sometimes unique, in comparison with other PCR methods.

\section{Acknowledgement}

This work was supported by the Russian Foundation for Basic Research and the administration of Krasnodar krai, project no. 16-44-230415.

\section{References}

1. Williams JGK, Kubelikn AR, Livak KJ, Rafalski JA, Tingey SV (1990) DNA polymorphism's amplified by arbitrary primers are useful as genetic markers. Nucleic Acids Res 18(122): 6531-6535.

2. Kil VI (2015) Use of High Specific RAPD Primers for PCR Analysis of Harmful and Beneficial Insect Populations. Russ Agric Sci 41(1): 21-25.

3. Kil VI, Besedina EN, Agas'eva IS, Ismailov V (2016) DNA polymorphism and genetic diversity of Habrobracon hebetor krasnodar population. Wschodnioeuropejskie Czasopismo Naukowe East European Scientific Journal 12: 49-51.

4. Kil VI, Tsigikalo IS, Agas'eva IS, Ismailov V (2015) RAPD-Analysis of Harmonia axyridis population in Krasnodar Krai. Russ Agric Sci 41(4): 230-233.

5. Kil VI, Ismailov VYa, Agas'eva IS, Besedina EN, Fedorenko EV (2012) Biological characteristics of the predatory two spotted stink bug Perillus bioculatus F. and PCR study of its phylogeny. Russ Agric Sci 38(3): 218-221.

6. Kil VI, Ismailov VYa, Agas'eva IS, Besedina EN, Fedorenko EV (2008) About polymorphism with RAPD markers in different taxons of the true bugs (Hemiptera). Agricultural Biol 1: 70-76.

7. Kil VI, Besedina EN, Tsigikalo IS (2015) PCR Analysis of Different Ladybird Species (Coleoptera, Coccinellidae) with Universal RAPD Primers. Russ Agric Sci 41(6): 446-449.

\section{Your next submission with Juniper Publishers will reach you the below assets}

Commons Attribution 4.0 License

DOI: 10.19080/ARTOAJ.2017.09.555769
- Quality Editorial service

- Swift Peer Review

- Reprints availability

- E-prints Service

- Manuscript Podcast for convenient understanding

- Global attainment for your research

- Manuscript accessibility in different formats

( Pdf, E-pub, Full Text, Audio)

- Unceasing customer service

Track the below URL for one-step submission https://juniperpublishers.com/online-submission.php 